\title{
Transferring Communicative Clues in Translation
}

\author{
Ma Pilar Navarro Errasti \\ University of Zaragoza \\ pnavarro@unizar.es
}

\begin{abstract}
In this essay I make use of the category communicative clue, as defined by Gutt (1991/2000), to explain certain differences between an original work and its various translations. Communicative clues are very useful analytical devices that show nuances of meaning and style. In the source texts, they sometimes go unnoticed. But when a translation is done the translator may come across these features and must desirably transfer them. Very frequently, however, they are ignored. Here a particular experience with translators shows how often these clues are overlooked.
\end{abstract}

\section{Introduction}

In this paper I would like to deal with what A.-E. Gutt, in his book Transiation and Relevance (1991/2000a) calls communicative clues (from now on CC) which I think represent a very useful class of analytical devices in translation studies. Rather than writing about this type of analytical categories from a theoretical point of view extensively I would like to offer the results obtained from a piece of research carried out in the field of translation.

According to Gutt, communicative clues are related to stylistic and textual properties of the original writing and their value he in that they help the reader to interpret utterances in the way intended by the communicator (Gutt, 1991: 127): 
(...) the point of preserving stylistic properties lies not in their intrinsic value, but rather in the fact that they provide clues that guide the audience to the interpretation intended by the communicator. We shall refer to such clues as communicative clues.

To some extent they are not intrinsic to the text but just clues that drive the reader's inferential processes in the writer's intended direction. A pragmalinguistic model such as relevance theory (RT) sees the transmission of information in two possible ways, namely explicitly and implicitly. Most likely communicative clues are to be seen in the latter way of transmission.

For me $\mathrm{CC}$ as analytic categories are extremely interesting in the analysis of ah type of texts in as much as they are winks of complexity prompted by the communicator in order to set up a certain commitment with his audience. In the case of translation studies, they give the analyst opportunities to explain many differences between the source text (ST) and the target or translated text (TT) that no other analytical devices can offer: frequently when reading an original work and its translation, although we can appreciate the translation is not bad, however we intuitively detect some lack of correspondence between both texts. Gutt thinks that this feeling may have two possible origins:

When one feels that a translation differs from the original it can be due to 1 . a misrepresentation of its communicative clues 2 . a mismatch in the contextual assumptions used to interpret it (Gutt, 2000b: 125).

The mismatch in the contextual assumptions used in the interpretation of the text will most probably be the source of important errors: the lack of correspondence between original and translation that leads us to think that the transferring of meaning has been poorly carried out. la that case we necessarily come to the conclusion that the translation is a bad one. Research oil this part of the translation process is very interesting but here it is the other factor of possible mistranslation which I intend to study. The misrepresentation of communicative clues or rather the lack of correspondence of these features between original and translated texts is extremely interesting from a cognitive pragmalinguistic stand such as RT.

In Navarro (2000) I dealt with the transmission of communicative clues and the usual lack of time professional translators have to carry out their versions. That led to interesting conclusions: there is no balance between the time used in recovering the original message and the time devoted to the wording of the new one. Now I shall rather concentrate on the analysis and description of clues in a very precise type of texts and several translations carried out by non-professional translators. The text is a propagandistic tourist text and the translators are fluent speakers of Spanish and English with no particular translation skills. here again the time factor plays an important role but I shall overlook that aspect for the moment to concentrate on other facts. Now the interest lies in the search and analysis of the various types of $\mathrm{CC}$ present in tourist propagandistic texts, their translation and the con sequences of the lack of correspondence. 


\section{The corpus}

To see the presence and the "fluency" in the transmission of clues the following process/corpus has been designed: a Spanish original has been selected and its translation into English. Then the new English text has been translated back into Spanish (without the presence of the Spanish original, of course). The Spanish source text (SST) was translated into the English target text (ETT) by a professional translator, both being printed and published with a lot of adequate graphic material in a tourist book. For the reverse translation, Spanish target text (STT), people with a high command of English and a good cultural level were selected (Spanish graduates in English Philology). They had no pictorial support; in other words, they only had the text to be translated. The Spanish translators carried out two different versions of each text: one with no dictionary and a very short time, another with no limit of time and all the means needed to give the rewording all necessary hues. The text showed no apparent difficulty for its translation.

The result of the analysis has been surprisingly rich and has revealed communicative clues difficult to be uncovered otherwise even for the readers of the SST, not to say for those of the ETT to whom many of the original clues did not even reach.

As already said, the corpus is a text of a propagandistic type taken from a luxurious book which is offered in high-standard hotels for the guests to read. The book can also be bought at a rather expensive price which means that the person who ordered it was confident of having got an appealing product.

Now that people move restlessly and travel from one city to another, from one comer of the world to another, from one landscape to another with almost compulsive eagerness, the authorities of the tourist areas have understood that it is necessary to tell people how charming and beautiful those places are, in order to attract all the potential visitors who otherwise would be captured by other places spoken of in a more appealing way, and this of course may have important economic effects. Thus the producer of the text intended to tell the readers how interesting and attractive the described places are and how much are they worth visiting.

The book is called Madrid Style 1999-2000. It was published by Book Style in Barcelona in 1999. It was the ${ }_{10}$ th edition. The editor, Carmen Canut, declares, as the aim of the book, to transmit the visitors of the city her passion for Madrid: "Si hemos logrado transmitir a los visitantes [...] la pasión que sentimos por Madrid, habremos conseguido nuestro objetivo". In the book there are chapters written by experts and well known writers. In particular we have analysed the chapter " 24 horas en Madrid. Un paseo por el tiempo" / "24 hours in Madrid. A walk through time", written by Pedro Montoliu, journalist and writer. He is also the official chronicler of the city. Mis text was translated into English by Philip V. Ortega. 


\section{A few words about the theory}

RT being a cognitive pragmatic theory lays emphasis on the fact that communication is intentional. In a tourist book, intention is a central issue and the reader must identify it such as the author envisaged. RT can help to decipher the intention behind the ostension in the same way it can account for the inferential processes related to the code which is one of the two means by which tourist propaganda is handled. Pictures are the other means intervening in the books. Pictures are of course extremely important in this type of literature. Intuitively we are sure that photographs and drawings in this type of books must be beautiful and, above all, convincing. We understand that they must show the prettiest side of the spot and we expect spectacular monuments, nice houses, nice rivers, nice mountains, and the like. Perhaps, as consumers, we do not have the same expectations about the text, but as researchers we must be conscious of this fact: the text has been written with similar intentions.

According to RT, the text, the codified message, is only an ostensive stimulus, out of which the reader, through inferential processes, must reconstruct not only the message, with ah its explicit and implicit load, but also the intention the producer of the propagandistic text wants to transmit. We presume it is very straightforward and very strong: just as much as the pictorial devices included in the book are inserted to create a positive convincing image, the text must be in agreement with the pictures next to which it appears and the intention of making most attractive every thing described must be present in every single utterance so that the reader can be positively impressed and convinced to visit the place. Consequently it is likely that every sentence would include some positive feature with respect to the place or parts of the place, its possibilities, its virtues, etc.

As RT would explain this information can be transmitted explicitly or implicitly. In general terms implicitness is more frequent in the communication process as it is at work from the very start (disambiguation, assignment of referents, enrichment); there is always more implicit than explicit communication too: implicit information is looser but it allows more contextual effects. On top of that, in the type of literature we are concerned with, an overtly, explicitly communicated positiveness would give way to a text too straightforward, too simplistic, letting the intention to be grasped too openly. On the contrary implicitness -being comparative, that is there may be more or less implicit information recovered by the audience - may be a means of compromising between writer and reader who shall be happy to share subtleties with the communicator. Communicative clues must be features intervening in the compromise between writer and reader. Then the transiator must transfer those, or at least equivalent features.

In Gutt (2000b: 153), he gives a more precise definition of CC: "communicative clues are a subset of the textual properties that are significant for the intended meaning. There would not be any difference in essence between a textual property and a communicative clue". But this is considering intralingual communication only. However, he postulates a more abstract concept in the case of interlingual communication: 
The situation changes when considering cross-lingual communication, and this is where it seemed helpful to form a more abstract concept than a textual property. The reason is that languages differ in the inventory of linguistic features or properties they have; hence property $A$ of language $X$ may simply not be found in language $Y$. Nevertheless one can very often find some means $B$ in language $Y$ that achieves the same or at least similar effect as property A did in language $\mathrm{X}$, assuming identical contexts. Properties that can be linked in this way are referred to as corresponding "communicative clues" (Gutt, 2000b: 153).

I agree better with the idea of a more abstract concept than a precise textual property, or at least I think that $\mathrm{CC}$ are not only textual properties, as Gutt does when talking about them as "corresponding communicative clues". He talks about equivalence among clues so that equivalent effects can be produced. But what are the so postulated equivalent effects? Apparently their role is "to guide the audience to the intended interpretation" (Gutt, 2000b: 155). To discuss the nature of $C C$ would take us too long and it is not my aim here either. As I said above I prefer to deal with a few examples and leave the discussion for another time. The only thing I would like to add is that thinking of communicative clues, Blakemore's idea of impressions comes to me: an utterance is more valuable not because the meaning is more precisely spelled out but because "it would have evoked a whole range of thoughts and impressions" (Blakemore, 1992: 10) but as she says "What is an impression? Not only is it hard to say what an impression is, but also it is not clear what, if anything, we can say about the mental processes involved in recovering one... The challenge, then, is to give a precise account of something that is very imprecise" (Blakemore, 1992: 10). And that is the problem with CC too.

Gutt (1991/2000a: 136) explains how CC may have different sources: they may be related to semantic representations, syntactic properties, phonetic properties, semantic constraints oil relevance, formulaic expressions, onomatopoeia, the very value of words and sound-based poetic properties. Although the presence of certain CC may be very clear, oil particular occasions it may be difficult to assign them to a precise origin. Certainly there is still a lot to be done about the nature, type and occurrence of $\mathrm{CC}$ in texts and translations, but probably everything will be easier after we have sought for them, discussed about them and seen how they are transferred. This is what I intend to do in the following lines.

\section{A few communicative clues}

The process explained above, devised to see the transmission of $\mathrm{CC}$ has easily uncovered some communicative clues, many of which, as we must have presumed, are not transferred by the translators. here I shall include just a few examples.

Let me begin with a very interesting case. I shall give first the Spanish source text (SST) then the English translated text (ETT) and finally the various versions into Spanish produced by the Spanish translators. I shall mention the translators using the first letter of their names: $\mathrm{M}, \mathrm{N}, \mathrm{C}$, etc. As most of the translators carried out two versions, a quick one 
and a more thoughtful, careful one for which all type of help was allowed, I will be added to $\mathrm{M}, \mathrm{N}, \mathrm{C}$, etc. to refer to the former version and 2 to refer to the latter:

SST: $\quad$ si el visitante se quiere llevar una impresión de esta gran ciudad.

ETT: if you wish to carry off an impression of this big city.

B1: si deseas llevarte una impresión) tener una idea, de esta gran ciudad.

B2: $\quad$ si se desea llevarse una buena impresión de esta ciudad.

M1: si uno desea llevarse una impresión de esta gran ciudad.

M2: $\quad$ si deseas crearte una impresión de esta gran ciudad.

J1: si Vd. desea llevarse una impresión de esta gran ciudad.

J2: $\quad$ si Vd. desea llevarse una impresión de esta gran ciudad.

Al: si lo que deseamos es lievamos una impresión general de esta gran ciudad.

MI: si lo que se desea es llevarse una impresión general de esta gran ciudad.

M2: si desea llevarse una impresión global de esta gran ciudad.

NI: $\quad$ si quieres tener una impresión de esta gran ciudad.

N2: $\quad$ si se quiere llevar una buena impresión de esta gran ciudad.

Cl: si desea hacerse una idea de como es esta gran ciudad.

C2: cuando lo que uno quiere es hacerse una idea completa de una ciudad tan grande como ésta.

K1: $\quad$ si desea visitar esta gran ciudad.

In this example, there is a very interesting multiple communicative clue. It is included in the segment esta gran ciudad, that has been turned by the professional English translator into this big city. To begin with, it is a feature contrary to what is the common practice: usually the translation of the English preceding adjective, e.g. handsome hoy is, perhaps lazily, retained by Spanish translators, yielding the same arrangement guapo chico. Thus the English unmarked sequence adjective + noun becomes a Spanish marked phrase, as the unmarked Spanish form is noun + adjective. In our example we have a case of unfaithfulness which although it does not affect the text greatly it can give the ETT a new tone and make it different to the original if the feature is frequently repeated. Let us point out that, contrarily to what happens in the English > Spanish direction, when translating the Spanish sequence noun + adjective into English, generally the translator rearranges the sequence into adjective + noun because the reverse arrangement is very frequently impossible in English as usually it is agrammatical. We can explain this fact easily by means of the analytical construct communicative clue. In this case we would be dealing with a syntactic and, probably, also semantic clue.

In esta gran ciudad translated as this big city the process that has taken place is the opposite to the one described above. The English translator has retained the Spanish arrangement which happens to coincide with the English unmarked form. Thus the Spanish original shows a feature of marked syntax that is probably impossible to transfer. But the marked occurrence of gran in esta gran ciudad, also embodies a semantic clue, the transmission of which would certainly be more important. In Spanish both una ciudad 
grande and una gran ciudad are possible but in the latter arrangement the meaning of the adjective rather than emphasising the large size of the city, a sense that is not excluded, also conveys the meaning of greatness - historically, artistically, scientifically speaking. For this reason gran not only makes reference to the fact that Madrid is big but more importantly, as syntactically it occurs in the marked position, it emphasises the many virtues of the city. Doubtless, this agrees with the intention underlying a propagandistic tourist text and the occurrence of the adjective in the original text is above all a clue that helps the interpretation of the following sentences.

The English translator, overlooking the marked Spanish syntax, has ignored both the meaning and the role of gran and the reader is not geared towards the intended interpretation. If he finally comes to an overall interpretation similar to the one intended by the original writer, he would have done so through a more costly process as he would have had to supply information from other sources, e.g. from the processing of the preceding or following sentences.

The behaviour of the Spanish translators has turned out to be very interesting. As a rule all of them come back to the original arrangement that they have not seen. Only two translators -I shall come back to them later oil- have done something different in their second translation. The others have been led by the English sequential dynamics -adjective + noun-given that this collocation is not a problem in the Spanish syntax. However, in doing so, they have not translated the true meaning of the unmarked English form. It could be said that they have been led by the syntax rather than by the semantics of the utterance. But if we look at the research schema carefully we can conclude that this has been the case with the English translator too. As a rule, then, the translators gave more importance to syntax both in the spontaneous quick translation and in the careful, polished one.

There are two exceptions in the corpus. $\mathrm{C} 2$ has translated: a big city as un a ciudad tan grande como esta. At first sight it is striking that the translation of a short phrase such as $a$ big city may have become such a long one as una ciudad tan grande como esta. The analysis of the facts may lead us to conclude that translator $C$ in his thoughtful, careful version has captured the true meaning and positional value of big in the ETT and has wanted to transfer them. he has given more importance to the translation of the true meaning at the expense of a lexical enlargement. However, he has come up against a problem. The exact translation of the phrase into a Spanish unmarked arrangement would be de esta ciudad grande but this sequence, although it is perfectly syntactic in Spanish, does not agree with the overall tone (intention?) of the text. In traditional terms, we might say that the new phrase has not the style of the rest of the text, but in the framework of RT aud CC we can say that this type of phrase does not yield the same clues to gear the inferential process in the intended direction. Thus the translator has been reluctant to select that version and he has preferred the longer token in order to be more faithful to the underlying clue. The problem is that doing so he has introduced an explicit comparative element. Probably he did so because of the scalarity character of the adjective grande, not present in gran. Scalarity has to be enriched inferentially; the translator probably thought that, being more explicit, he was closer to the 
meaning of the sentence that he wished to translate faithfully. In this case he was worried by the semantics of the utterance although that brought bim problems.

The other translation that differed from the majority, si se desea llevarse una buena impresión de esta ciudad, avoided any future trouble just ignoring the adjective. Possibly the translator did so because he was conscious of the problem, suspiciously enough this is the second, carefully done version, although in the first one he had translated as gran ciudad.

A very interesting phenomenon that can be studied within the framework of the $\mathrm{CC}$ is the use, by the Spanish translators, of $\mathrm{T} / \mathrm{V}$ forms. The original Spanish writer had selected a noun, el visitante, although other nouns such as turista, viajero, etc. might have been chosen with a similar value. However visitante has a different shade. It is not a very frequent item but it is the most appropriate word if one wants the audience to understand that he is not referring to a person who passes through, having looks at occasional monuments shown by a tourist guide, or the person who stays one or to days doing things in a hurry. $E l$ visitante goes, not in a hurry, stays and is pervaded by what surrounds him. The item, then, that embodies that clue of plenty of time and enjoyment is lost and the English translator ignoring ah subtleties has selected the second person pronoun whose referents range from the reader himself to an impersonal grammatical subject. This has nothing to do with the original intention and, besides the loss of the communicative clue, the resulting product is a poor translation. However, you has to be reinterpreted by the "second round" translators; they know the meaning and the use of the word and they try to reproduce the clue they may have captured. They can choose between a second person or an impersonal pronoun. In Spanish there exists the added problem of the multiple choice for the second person: the formal usted and the informal tú, together with their respective plurals.

In my opinion the selection of one or another form is related to CC. Grammar allows all four translations. The election of one form depends on how you want to be understood, on how you want the reader to carry out his inferential processes: tú or vosotros would lead the audience to a level different to that of gran ciudad. $V d$. might maintain it. The analysis of the Spanish translations show all possibilities:

SST: si el visitante se quiere llevar una impresión de esta gran ciudad.

ETT: if you wish to carry off an impression of this big city.

B1: si deseas llevarte una impresión, tener una idea, de esta gran ciudad.

B2: si se desea llevarse una buena impresión de esta ciudad.

Ml: si uno desea llevarse una impresión de esta gran ciudad.

M2: si deseas crearte una impresión de esta gran ciudad.

J1: en efecto si Vd desea llevarse una impresión de esta gran ciudad.

$\sqrt{ } 2: \quad$ si Vd. desea llevarse una impresión de esta gran ciudad.

A1: si lo que deseamos es llevarnos una impresión general de esta gran ciudad.

H1: si lo que se desea es llevarse una impresión general de esta gran ciudad.

H2: $\quad$ si desea llevarse una impresión global de esta gran ciudad.

$\mathrm{Nl}$ : si quieres tener una impresión de esta gran ciudad. 
N2: si se quiere llevar una buena impresión de esta gran ciudad.

$\mathrm{Cl}$ : si desea hacerse una idea de como es esta gran ciudad.

C2: cuando lo que uno quiere es hacerse una idea completa de una ciudad tan grande como ésta.

$\mathrm{KI}$ si desea visitar esta gran ciudad.

Thus the second person pronoun poorly used by the English translator has been interpreted in the Spanish versions as impersonal four times:

B2: $\quad$ si se desea llevarse.

M1: si uno desea llevarse.

H1: si lo que se desea,

C2: cuando lo que uno quiere.

as the formal $V d$. (V form) seven times:

J1: $\quad$ si Vd desea llevarse.

J2: si Vd. desea llevarse.

N2: si se quiere llevar.

$\mathrm{H} 2$ : $\quad$ si desea llevarse.

N2: si se quiere llevar.

$\mathrm{Cl}$ : si desea hacerse una idea.

$\mathrm{Kl}$ : $\quad$ si desea visitar.

or as the informal second person $t u ́$, three times:

B1: si deseas llevarte.

M2: si deseas crearte.

Nl: $\quad$ si quieres tener.

Curiously one of the translators has used the including first person plural:

Al: si lo que deseamos es llevarnos.

Thus the translators have made use of all the possibilities Spanish allows, however the analysis shows that the most frequently interpreted form is the formal $V d$ (V form); the second most frequent is the impersonal equivalent; then the informal second person tu and finally there is a curious interpretation as $1^{\text {st }}$ person plural form.

So we see that most of the translators have opted for the greatest degree of formality and that is in agreement with the tone of the piece of writing they have at hand where words and 
collocations such as gran ciudad or llevarse una impresión - to which I shall refer nowprovide clues for the processing in a certain direction.

The same utterance is good for a further example. I shall refer to the collocation and value of impresion, its translation into English and the translators' reinterpretation into Spanish. Impresion is an item that may occur with verbs such as hacer, (hacerse una impresión), causar (causar (una) impresión), crear(se) (crear(se) una impresión), dar (dar (una) impresión) or llevarse, as in the SST, llevarse una impresión. All collocations convey slight differences of meaning. However, very frequently, in everyday informal speech, the various expressions may be used as synonymous, disregarding the different shades of meaning; but this only backs up the idea that the code is merely a stimulus that activates the background contextual assumptions and that once the right ones have been brought to bear, the effects are the intended results, just as much as it happens when a slip of the tongue occurs.

Now I shall deal with the utterances used by the translators. I shall repeat the sentences, with the forms duly emphasised, for easier observation:

SST: si el visitante se quiere llevar una impresión de esta gran ciudad.

ETT: if you wish to carry off an impression of this big city.

B1: si deseas llevarte una impresión / tener una idea, de esta gran ciudad.

B2: si se desea llevarse una buena impresión de esta ciudad.

Ml: si uno desea llevarse una impresión de esta gran ciudad.

M2: si deseas crearte una impresión de esta gran ciudad.

J1: en efecto si Vd desea llevarse una impresión de esta gran ciudad.

J2: $\quad$ si Vd. desea llevarse una impresión de esta gran ciudad.

A1: si lo que deseamos es llevarnos una impresión general de esta gran ciudad.

Hl: silo que se desea es llevarse una impresión general de esta gran ciudad.

H2: si desea llevarse una impresión global de esta gran ciudad.

N1: si quieres tener una impresión de esta gran ciudad.

N2: si se quiere llevar una buena impresión de esta gran ciudad.

$\mathrm{Cl}$ : si desea hacerse una idea de como es esta gran ciudad.

C2: cuando lo que uno quiere es hacerse una idea completa de una ciudad tan grande como ésta.

K1: si desea visitar esta gran ciudad.

The translations range from: crearse una impresión, tener una impresión, or hacerse una idea, to visitar, which is such a freely done translation that it is not worth commenting on. Llevarse una impresión, used nine times is by far the most recurrently employed. However, in spite of this outstanding number, some questions arise. Why do all translators not use this very expression? Why do two translators add adjectives (buena on one occasion, and global in the case of $\mathrm{H} 2$ ) to impresión? Why does another translator who had not selected llevarse una impresión, curiously add an adjective to his noun, idea completa? 
As mentioned above, we are touching on expressions with very close meanings (both in English and Spanish); but the diversity shown in the translations suggests that there may be a concealed problem which, rather than being a textual problem, may be more closely related to the communicator's intention of handling the message to be processed in a certain way.

In the Spanish original, si el visitante se quiere llevar una impresión de esta gran ciudad, the chronicler puns with a double choice: he selects the verb llevar but he leaves impresión without an adjective. In fact, one cannot llevarse una impresión in Spanish; one has to llevarse una buena/mala impresión, for instance. This expression needs a modifier and that is why the translators struggle to supply the missing one. Curiously they add the adjective not only in those sentences with the verb llevar (llevarnos una impresion general, llevar una buena impresión, llevarse una impresión global) but also when they choose another expression, hacerse una idea completa. We should not overlook the fact that, rather than in the first more spontaneous translation, most of the adjectives appear in the second, more carefully done one. The former is perhaps a more automatic translation where only very strikingly unidiomatic and agrammatical utterances are substituted and corrected. In the latter the translator has longer time to think about linguistic subtleties and it is then when they notice the oddity of the construction.

The lack of an adjective in lievarse una impresión, besides being a non-standard sequence, conveys a somewhat modified meaning. If the impression one gets is not modified by an adjective, the referent of impression might come closer to that of idea, for instance, as C2 suggests, una idea completa, and in this case hacerse is the appropriate verb. M2's translation, crearte una impresion, also shows a desire to come closer to the meaning of hacerse una idea in the sense of a more comprehensive knowledge of the city. In my opinion, this translator has captured the problem, he wants to solve it but at the same time he wants to be as faithful to the original text as he can. In this line he retains impresión but he considers the verb crearse more adequate for the correct expression.

There is a final question to be answered. Why did the chronicler not use an adjective with impresión? Did he write a wrong sentence? Was it a slip? My opinion is that he was perfectly conscious of what he was doing and he was doing that very intentionally.

In the first place the conditions underlying a tourist propagandistic book lead the reader to bring to bear a context that should help him to process the utterances in a positive direction: everything is good, worth being visited, so that the impresion you may take away is necessarily good, excellent. On top of that the chronicler's intention underlying the utterance is still more apparent if we observe the sequence as a whole. In a sentence such as llevarse una impresión de esta gran ciudad, the largely discussed value of the adjective -one can get a bad impression of a ciudad grande, but never of a gran ciudad-makes the explicit expression of positiveness unnecessarily redundant and irrelevant (more processing effort for the same effect). And what is more important, redundancy and explicitness would have given way to a plain and coarse style which is not that intended by the author. He wants his words to be processed in a special manner. The writer wants his readers to come to the meaning implicitly. The meaning is more imprecise but implicitness allows for various 
contextual effects: a good impression, a very good impression, an excellent impression, etc. Here the readers are offered a clue that the English translator disregards posing a problem to the Spanish translators.

\section{A few conclusions}

The few points discussed above in relation to $\mathrm{CC}$ lead us towards a very straightforward conclusion: we have a field of endless possibilities in front of us. A second point would be that $\mathrm{CC}$ can be absolutely hidden and in order to detect their presence in original and translated texts it is necessary to implement corpora and processes that make all types of features, disguised within the different linguistic and textual components, come to surface. As mentioned above these clues present but not directly apparent in the texts are of capital importance to establish a particular type of relationship between author and reader. In the case of a tourist book of the type we have been dealing with, there seems to be an underlying two-way intention of convincing-letting someone being convinced about the convenient visit of such and such a place. If the intention on the writer's behalf is too explicitly conveyed it may be self-destroying and may lead to unwanted effects. Nevertheless an intention subtly handled, not by means of explicit devices but as the result of inferential processes carried out from implicit premises, may give way to occasions of complicity that may let the author direct his reader in the intended way.

The subtlety and complexity of CC make them a dangerous two-fold weapon in translation studies. It would be desirable that a good foreign version of any text should transfer them or at least features of equivalent value so that the reader of the translated text could be equally guided in his inferential processes in the same direction, and towards the original writer's intended meaning. But this is far from what happens even in translations carefully purposefully designed to be excellent.

To end with let me say that, although it is extremely dangerous to obtain far-reaching conclusions from such a small piece of research, however a light tendency seems to appear towards the priority of syntax over semantics as if there were an underlying inertia or a more powerful force in the translators' behaviour. Is that only the translators' own tendency or is it a universal feature? Perhaps we could answer the question if we look for further evidence in texts and translated texts.

\section{Corpus}

Montolíu, P. (1999-2000): "24 horas en Madrid. Un paseo por el tiempo". In C. Canut, ed., Madrid Style. Barcelona: Book Style. (1999-2000): "24 hours in Madrid. A walk through time". Trans. P.V. Ortega. In C. Canut, ed., Madrid Style. Barcelona: Book Style. 


\section{Works Cited}

Blakemore, D. (1992): Understanding Utterances: An Introduction to Pragmatics. Oxford: Blackwell.

Gutt, E.A. (1991): Translation and Relevance. Cognition and Context. Oxford: Blackwell. . (1998): "Pragmatic aspects of translation: Some relevance theory observations". In L. Hickey, ed., The Pragmatics of Translation. Clevedon: Multilingual Matters. . (2000a): Translation and Relevance. Cognition and Context ( $2^{\text {nd }}$ edition). London: St. Jerome Publishing.

. (2000b): "Textual properties, communicative clues and the translators". In $M^{a} . P$. Navarro Errasti et al., eds., Transcultural Communication: Pragmalinguistic Aspects. Zaragoza: Anúbar.

Leech, G. (1983): Principles of Pragmatics, London: Longman.

Levinson, S.C. (1983): Pragmatics. Cambridge: Cambridge University Press.

Navarro Errasti, $M^{\mathrm{a}}$.P. (1995): "Communicative clues in Sir Gawin and the Green Knight". In A.H. Jucker, ed., Historical Pragmatics. Amsterdam: John Benjamins.

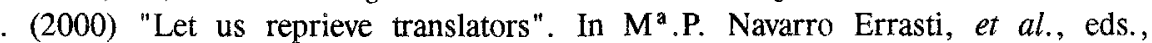
Transcultural Communication: Pragmalinguistic Aspects. Zaragoza: Anúbar.

Sperber, D. and D. Wilson (1986): Relevance: Communication and Cognition (second edition, 1995). Oxford: Blackwell. 